\title{
En fire måneder gammel gutt med manglende vektøkning
}

\author{
Manglende vektøkning hos spedbarn kan ha mange årsaker. Tilstanden \\ krever grundig utredning når de vanligste årsakene er utelukket. \\ I denne kasuistikken avdekket utredningen en svært sjelden diagnose.
}

Christoph Norden

christoph.norden@helse-fonna.no

Terje Alsaker

Heiko Bratke

Barneseksjonen

Haugesund sykehus
En fire måneder gammel gutt ble henvist poliklinisk til barneklinikken pga. manglende vektøkning. Gutten var født til termin etter et normalt svangerskap. Fødselsvekten var $3,8 \mathrm{~kg}$. Han hadde vært frisk siden fødselen, men vektkurven hadde etter hvert flatet ut og krysset mer enn to hovedprosentiler (fig 1). Storesøsteren hans hadde melkeallergi som spedbarn, ellers var det ingen sykdommer i familien. Ved første konsultasjon var vekten under 2,5-prosentilen, mens lengdeveksten var normal. Moren hadde ammet ham, og de siste to ukene før konsultasjonen hadde han i tillegg fått kumelksbasert morsmelkerstatning, etter råd fra fastlegen. Moren hadde tidligere prøvd å unngå kumelksprodukter, uten effekt på guttens vekt. Han hadde avføring med normal konsistens én gang per uke. Bortsett fra lett nedsatt hodekontroll, var det normale funn ved klinisk undersøkelse. Gutten virket blid og fornøyd. Laboratorieprøver ved ankomst viste verdier av natrium på 166 mmol/l (135-145 mmol/l) og klorid på 127 mmol/l (98-106 mmol/l). Differensialtelling, syre-base-status, blodsukker og thyreoideastimulerende hormon (TSH) viste normale funn.

Betegnelsen manglende vektøkning hos barn brukes vanligvis når et barns vekt for alderen er under 2,5-prosentilen eller når vektkurven har krysset to hovedprosentiler (1). Manglende vektøkning er ikke en diagnose, men en tilstand som alltid skal føre til videre utredning og er en av de hyppigste henvisningsårsakene til barneavdelingene. Det finnes mange forskjellige årsaker til manglende vektøkning, blant annet utilstrekkelig kaloriinntak, nedsatt matopptak eller økt stoffskifte. Utilstrekkelig kaloriinntak, for eksempel grunnet ammeproblemer, er den hyppigste årsaken til manglende vektøkning hos spedbarn, men alvorlige lidelser som medfødt hjertefeil, kronisk infeksjon eller kronisk lungesykdom skal alltid overveies. Hos vår pasient var det ingen tegn til alvorlig sykdom ved første konsultasjon. Bortsett fra hypernatremi, som ble tolket som hyperton dehydrering, var blodprøvene normale.

Hyperton dehydrering er oftest forårsaket av tap av hypoton væske, f.eks. ved diaré.
I de første leveukene ses det derimot oftest $\mathrm{i}$ forbindelse med nedsatt væskeinntak og er hyppigere hos barn som blir ammet enn hos barn som blir flaskeernært. Hos vår pasient var det ingen tegn til økt væsketap, og problemer med ammingen ble derfor antatt å være den mest sannsynlige årsaken til manglende vektøkning og dehydrering, muligens i forbindelse med melkeproteinallergi.

Pasienten ble måltidsveid og tok veldig varierende mengder melk fra brystet. Sugeteknikken ble vurdert til ikke å være optimal. Han ble sendt hjem på full flaskeernæring med en morsmelkerstatning basert på hydrolysert kasein som brukes ved melkeallergi. Ved kontroll fire dager senere var vekt og natriumverdi i serum uforandret. Pasienten ble da innlagt for videre utredning. Utvidede blodprøver viste serum-osmolalitet på 329 mosmol/kg (275-290 mosmol/kg) og normalt blodsukker. Han hadde en lav urin-osmolalitet på $160 \mathrm{mosmol} / \mathrm{kg}$ og en lav urin-natrium under $20 \mathrm{mmol} / \mathrm{l}$. Urinstiks var negativ for glukose, og urinen var påfallende fargeløs. Pasienten fikk blærekateter, og døgndiuresen ble $i$ de følgende tre dager målt til 550-700 ml. Dette tilsvarer 1,8-2,3 l/m²/døgn. Ultralyd av nyrer og urinveier var normal.

Polyuri hos barn defineres som døgndiurese over $21 / \mathrm{m}^{2}$ (2). Når hyperglykemisk polyuri er utelukket, finnes to hovedårsaker til polyuri: primær (eller psykogen) polydipsi (høyt væskeinntak) og diabetes insipidus. Et barn på fire måneder drikker ikke mer enn sitt behov. Ved polydipsi forventer man dessuten et lavt eller normalt s-natrium. Polydipsi var derfor ikke en sannsynlig årsak til pasientens polyuri. Hypernatremi samtidig med lav u-osmolalitet tyder på manglende evne til å konsentrere urinen og dermed på diabetes insipidus.

Diabetes insipidus inndeles i sentral og nefrogen type. Sentral (nevrogen) diabetes insipidus skyldes insuffisient sekresjon av antidiuretisk hormon (ADH) i hypofysen, noe som fører til utilstrekkelig reabsorpsjon av vann i nyrene og dermed til vanntap. Denne tilstanden er ofte idiopatisk, men oppstår også posttraumatisk, ved medfødt hypo- 
Tabell 1 Kort oversikt over noen vesentlige verdier i forløpet

\section{Behandlingsdag}

\begin{tabular}{lrrrrrr} 
& 1 & 2 & 3 & 4 & 8 & 21 \\
Hydroklortiazid (mg/kg/d) & - & - & 0,1 & 0,1 & 0,1 & 0,1 \\
S-natrium (mmol/l) & 166 & 162 & 152 & 146 & 144 & 143 \\
S-osmolalitet (mosmol/kg) & 329 & 320 & 302 & 290 & 286 & 284 \\
Vekt (g) & 5230 & 5340 & 5310 & 5305 & 5310 & 5735 \\
Væsketilførsel (ml) & 773 & 1214 & 967 & 1029 & ikke målt & ikke målt \\
Døgndiurese (ml) & 524 & 626 & 698 & 581 & ikke målt & ikke målt \\
\hline
\end{tabular}

pituitarisme, intracerebral tumor, hypoksisk encefalopati eller andre sjeldnere tilstander (3). Det finnes også en familiær variant som er meget sjelden. Ved nefrogen diabetes insipidus er hypofysens ADH-sekresjon normal, men nyrene er i varierende grad resistente mot $\mathrm{ADH}$, noe som også fører til renalt vanntap (4). Denne tilstanden kan være hereditær eller ervervet. Ervervet nefrogen diabetes insipidus er oftest forårsaket av litiumintoksikasjon eller hyperkalsemi, men ses også i forbindelse med mange nyresykdommer.

Gutten hadde normale verdier av TSH, adrenokortikotropt hormon (ACTH), aldosteron, veksthormon, IGF-log IGF-bindingsprotein 3
(IGFBP-3), og dermed ingen tegn til medfødt hypopituitarisme. Det var ingen holdepunkter for gjennomgått asfyksi under fødselen. Det ble gjennomført DDAVP-test (DDAVP = deamino-8-D-arginin vasopressin, et syntetisk $A D H$-derivat), der pasienten fikk $10 \mu \mathrm{g}$ DDAVP intranasalt uten etterfølgende stigning av u-osmolalitet. Det ble også målt faktor VIII og von Willebrands faktor-antigen og von Willebrands faktor-aktivitet før og tre timer etter DDAVP. Ingen av disse faktorene steg etter DDAVP. Pasienten fortsatte med morsmelkerstatning og fikk de følgende tre dager i tillegg glukose $5 \mathrm{mg} / \mathrm{ml}$ intravenøst. Dette hadde ingen effekt på vekten eller hypernatremien.

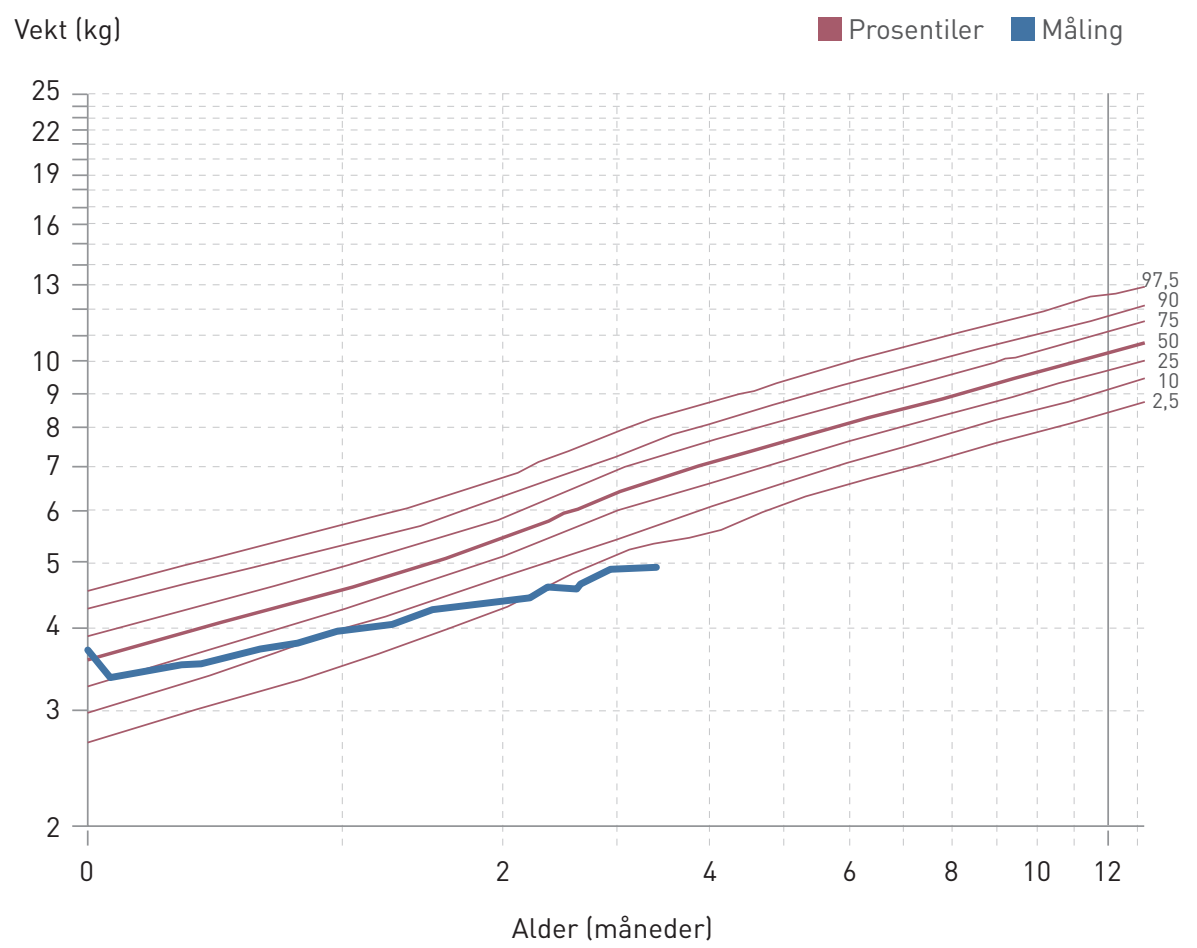

Figur 1 Pasientens vektkurve ved henvisning til barneklinikken

Første skritt for å sikre diagnosen diabetes insipidus er vanligvis en tørstetest der man måler om pasienten er i stand til å konsentrere urinen etter og under tørste. Vi gjennomførte ikke en tørstetest hos denne pasienten, da testen er kontraindisert ved hypernatremi. S-osmolaliteten var med 329 $\mathrm{mosmol} / \mathrm{kg}$ svært forhøyet. Som fysiologisk svar på en slik s-osmolalitet ville man forvente en sterkt konsentrert urin med en høyere u-osmolalitet enn den aktuelle s-osmolaliteten. Da u-osmolaliteten hos vår pasient kun var $160 \mathrm{mosmol} / \mathrm{kg}$ anså vi diagnosen diabetes insipidus som sikker (2).

Å skille mellom sentral og nefrogen diabetes insipidus kan være en utfordring, spesielt hos spedbarn. Ved sentral diabetes insipidus forventer man stigning av u-osmolaliteten som en effekt av DDAVP-tilførsel. En stigning under $100 \mathrm{mosmol} / \mathrm{kg}$ tyder sterkt på at årsaken heller er nefrogen. Da u-osmolaliteten ikke steg etter DDAVP, anså vi diagnosen nefrogen diabetes insipidus som sikker.

Ved nærmere anamnese viste det seg at moren til pasienten hadde nattenurese som barn og at hun alltid har hatt nokturi og behov for å drikke om natten. Pasientens storesøster drakk også rikelig og tisset minst en gang om natten.

Det finnes to forskjellige reseptorer for ADH i nyrene, V1 og V2. Omtrent $90 \%$ av pasienter med hereditær nefrogen diabetes insipidus har en defekt i V2-reseptoren (5). Genet for V2-reseptoren er lokalisert på Xkromosomet, og derfor er det oftest gutter som får sykdommen. Jenter med bærertilstand kan være asymptomatiske eller ha lettgradig polyuri. En ekstrarenal virkning av DDAVP er økt frigjøring av faktor VIII og von Willebrands faktor (6). Denne mekanismen er V2-reseptormediert og kunne ikke registreres hos vår pasient. Sett sammen med familieanamnesen var det mest sannsynlig at pasienten hadde en defekt i V2reseptoren.

Tre dager etter at pasienten ble innlagt startet han med hydroklortiazid $0,1 \mathrm{mg} / \mathrm{kg} / \mathrm{d}$. I løpet av to dager falt s-natrium fra 162 $\mathrm{mmol} / \mathrm{l}$ til $146 \mathrm{mmol} / \mathrm{l}$, intravenøs væske ble seponert og pasienten kunne skrives ut (tab 1). Han ble ernært med morsmelk/ erstatning i forhold til alder og vekt, periodevis beriket med rapsolje, siden vekten ikke $ø k t e$ tilfredsstillende. Han fikk i tillegg drikke vann regelmessig. Allmenntilstanden var uendret god som før behandlingsoppstart. Med dette opplegget og uendret dose hydroklortiazid la han i de følgende åtte ukene på seg nesten $700 \mathrm{~g}$. S-natrium har ligget mellom $143 \mathrm{mmol} / \mathrm{log} 150 \mathrm{mmol} / \mathrm{l}$. 
Nefrogen diabetes insipidus er vanskeligere å behandle enn sentral diabetes insipidus, da DDAVP ikke har noen effekt. En salt- og proteinfattig diett bidrar til redusert væsketap, men er ikke indisert hos barn i vekst. Medikamentelt brukes tiaziddiuretika, ikke-steroide antiinflammatoriske midler (NSAID) eller amilorid. Medisinene brukes alene eller i kombinasjon. Vår pasient hadde god og umiddelbar effekt av hydroklortiazid og har til nå ikke hatt bruk for supplerende medisin.

\section{Diskusjon}

Manglende vektoppgang hos spedbarn ses ofte på barneavdelinger og kan ha mange forskjellige hyppige og mindre hyppige årsaker. Vår pasient hadde en meget sjelden årsak til manglende vektøkning. Insidensen for alle typer diabetes insipidus hos barn er estimert til å være $0,003 \%$. For hereditær nefrogen diabetes insipidus er insidensen ikke beskrevet.

De klassiske symptomene på diabetes insipidus er polyuri som fører til dehydrering og kompensatorisk polydipsi. Polyuri kan være vanskelig å registrere for foreldrene hos barn som bruker bleier. Polydipsi bemerkes ofte først når barnet blir større og når tiden mellom måltidene blir lengre. Når kompensatorisk økt væskeinntak ikke kan oppnås, finner man ofte moderat til svær hypernatremi. Det er derfor viktig å overveie diabetes insipidus hos spedbarn med hyperton dehydrering der man ikke finner en annen åpenbar forklaring.

De fleste spedbarn med diabetes insipidus debuterer med feber, oppkast eller dehydrering. Noen har dårlig vektøkning som første symptom. Inntak og utskilling av store mengder vann over lang tid kan føre til hydronefrose, hydroureter og dilatert blære $(7$, 8). Hos vår pasient ble diagnosen stilt ved fire måneders alder, og behandlingen ble startet tidlig. Barnet viste på dette tidspunktet dårlig vektøkning, men var ellers i god allmenntilstand. Det var ingen tegn til dilatasjon av urinveiene.

Hereditær nefrogen diabetes insipidus er forårsaket av en defekt i ADH-signaltransduksjonen i nyrens samlerør. Dette fører til insuffisient respons på $\mathrm{ADH}$ og dermed til en forstyrrelse i kroppens væskehomøostase. Mutasjonen er oftest lokalisert i genet for V2-reseptoren, som hos vår pasient. En sjeldnere variant er mutasjoner i genet som koder for akvaporinkanalen. Her er arvegangen autosomal og kan være både dominant og recessiv.

Konstellasjonen hypernatremi og lav uosmolalitet ga diagnosen diabetes insipidus. Manglende stigning i u-osmolaliteten ved DDAVP-testen ga den endelige diagnosen nefrogen diabetes insipidus. Til tross for ekstra tilførsel av saltfri væske i begynnel- sen kunne det høye natriumnivået ikke korrigeres. Dette var først mulig etter oppstart med hydroklortiazid. Den eksakte virkningsmekanismen av hydroklortiazid ved nefrogen diabetes insipidus er ikke avklart. Det fører til reduksjonen av diurese, sannsynligvis gjennom natrium- og vannreabsorpsjon proksimalt i samlerøret der akvaporinene er lokalisert (9). Mål for behandlingen er å oppnå et tilstrekkelig kaloriinntak og å forhindre episoder med svær dehydrering. Dersom man ikke kommer i mål med ovennevnte behandlingsopplegg, kan ikkesteroide antiinflammatoriske midler (spesielt indometacin eller ibuprofen) som tilleggsbehandling prøves $(10,11)$.

De fleste pasienter med nefrogen diabetes insipidus har dårlig vektoppgang og lengdetilvekst. Man antar at dette er sekundært til høyt væskeinntak som fører til manglende inntak av kalorier (12). Vår pasient har lagt på seg nesten $700 \mathrm{~g}$ siden behandlingsoppstart, svarende til $12,5 \mathrm{~g}$ per dag. I alderen 3-6 måneder forventer man en daglig vektøkning på 17-18 g (13). Etter ettårsalderen har de fleste pasienter med nefrogen diabetes insipidus tatt igjen vekten, og de fleste pasienter ligger under ett standardavvik høyde (12).

Pasienten følges opp på barneendokrinologisk poliklinikk med jevnlig kontroll av vekt, lengde og elektrolyttstatus. Årlige kontroller med ultralyd av nyrer og urinveier er også planlagt, da det er en mulighet for at den store urinmengden på sikt kan føre til blæredysfunksjon med hydronefrose og nyresvikt som følge $(8,14)$.

Barnets foreldre har gitt samtykke til at artikkelen blir publisert.

\section{Christoph Norden (f. 1977)}

er lege i spesialisering i barnesykdommer. Han er konstituert overlege.

Forfatter har fylt ut ICMJE-skjemaet og oppgir ingen interessekonflikter.

\section{Terje G. Alsaker (f. 1948)}

er spesialist i barnesykdommer, overlege, APLSinstruktør og Norsk barnelegeforenings representant i styret for Norsk Resuscitasjonsråd. Forfatter har fylt ut ICMJE-skjemaet og oppgir ingen interessekonflikter.

\section{Heiko Bratke (f. 1971)}

er spesialist i barnesykdommer, med subspesialisering i pediatrisk endokrinologi og diabetologi fra Tyskland, er overlege samt leder i interessegruppe for endokrinologi og metabolisme i Norsk barnelegeforening.

Forfatter har fylt ut ICMJE-skjemaet og oppgir ingen interessekonflikter.
Litteratur

1. Markestad T. Klinisk pediatri. Bergen: Fagbokforlaget Vigmostad \& Bjørke, 2003: 19

2. Kliegman RM, Stanton BF, Schor NF et al. Nelson textbook of pediatrics. 19. utg. Oxford: Elsevier Saunders, 2011: 1882

3. Kliegman RM, Stanton BF, Schor NF et al. Nelson textbook of pediatrics. 19. utg. Oxford: Elsevier Saunders, 2011: 1883

4. Di lorgi N, Napoli F, Allegri AE et al. Diabetes insipidus-diagnosis and management. Horm Res Paediatr 2012: 77: 69-84

5. Sands JM, Bichet DG. Nephrogenic diabetes insipidus. Ann Intern Med 2006; 144: 186-94.

6. Bichet DG, Razi M, Lonergan M et al. Hemodynamic and coagulation responses to 1-desamino[8$\mathrm{D}$-arginine] vasopressin in patients with congenital nephrogenic diabetes insipidus. N Engl J Med 1988; 318: $881-7$

7. Kliegman RM, Stanton BF, Schor NF et al. Nelson textbook of pediatrics. 19. utg. Oxford: Elsevier Saunders, 2011: 1883-4.

8. Ulinski T, Grapin C, Forin V et al. Severe bladder dysfunction in a family with ADH receptor gene mutation responsible for X-linked nephrogenic diabetes insipidus. Nephrol Dial Transplant 2004 19: $2928-9$

9. Earley LE, Orloff J. The mechanism of antidiuresis associated with the administration of hydrochlorothiazide to patients with vasopressin-resistant diabetes insipidus. J Clin Invest 1962; 41: 1988-97.

10. Monnens L, Jonkman A, Thomas C. Response to indomethacin and hydrochlorothiazide in nephrogenic diabetes insipidus. Clin Sci (Lond) 1984: 66 $709-15$.

11. Knoers N, Monnens LA. Amiloride-hydrochlorothiazide versus indomethacin-hydrochlorothiazide in the treatment of nephrogenic diabetes insipidus. J Pediatr 1990; 117: 499-502.

12. van Lieburg AF, Knoers NVAM, Monnens LAH. Clinical presentation and follow-up of 30 patients with congenital nephrogenic diabetes insipidus. J Am Soc Nephrol 1999; 10: 1958-64.

13. Frank DA. Failure to thrive. I: Augustyn M, Zuckerman B, Caronna EB. The Zuckerman Parker Handbook of developmental and behavioral pedia tric in primary care. 3. utg. Philadelphia, PA: Lippincott Williams \& Wilkins, 2011: 204

14. Uribarri J, Kaskas M. Hereditary nephrogenic diabetes insipidus and bilateral nonobstructive hydronephrosis. Nephron 1993; 65: 346-9.

Mottatt 2.8. 2013, første revisjon innsendt 14.12. 2013, godkjent 3.2. 2014. Redaktør: Sigurd Høye. 